\title{
IMPLEMENTATION OF THE RAD MODEL OF SOFTWARE APPLICATION FOR POPULATION DATA MANAGEMENT VILLAGE OF SUKAWENING BOGOR
}

\author{
Sismadi \\ Program Studi Sistem Informasi Akuntansi \\ Universitas Bina Sarana Informatika \\ www.bsi.ac.id \\ sismadi.ssm@bsi.ac.id
}

\begin{abstract}
Abstrak
Pelayanan umum keadministrasian penduduk sangat penting pengelolaannya, data aman, penyimpanan baik, pencarian mudah sewaktu dibutuhkan. Kondisi ini belum terpenuhi bila pengelolaan data dilakukan secara manual dengan jumlah data besar. Desa sukawening terletak dibagian selatan bogor mengalami kondisi ini, pengelolaan data penduduk dilakukan secara manual dengan bantuan Microsoft excel, menjadi kendala dalam mewujudkan pelayanan keadministrasian penduduk, meliputi SKU, berkas kelahiran, kematian, pindah dan kedatangan jiwa. Dibutuhkan solusi untuk mewujudkan pelayanan penduduk yang cepat, efisien dan aman dari kondisi hilang dan rusak. Pemecahan masalah yang digunakan penelitian ini adalah membangun sistem aplikasi yang ditujukan untuk mengelola data penduduk. Sistem dibangun berbasis web dengan model $R A D$, tool framework codeigniter. Dengan terwujudnya sistem aplikasi maka pengelolaan data kependudukan desa sukawening sesuai harapan.
\end{abstract}

Kata kunci: Implementasi Model RAD, Sistem Administrasi Desa, Sistem Pelayanan Umum

\begin{abstract}
Public administration services for the population are very important for management, safe data, good storage, easy search when needed. This condition has not been fulfilled if data management is done manually with large amounts of data. Sukawening village, located in the southern part of Bogor, experience this condition, the management of population data is done manually with the help of Microsoft Excel, which is an obstacle in realizing resident administrative services, including SKU, births, deaths, moving and arrival files. Solutions are needed to realize fast, efficient, and safe services for residents from lost and damaged conditions. The solution to the problem used in this research is to build an application system that is intended to manage population data. The system is built based on the web with the RAD model, a Codeigniter framework tool. With the realization of the application system, the management of population data in the Sukawening village is as expected.
\end{abstract}

Keywords: Implementation of the RAD Model, Village Administration System, Public Service System

\section{INTRODUCTION}

Population growth which continues to increase every year(BPS, 2019) makes population data management must be handled seriously and professionally because the population determines the direction and policies and development of an area, as well as the smallest government administrative services in the region. Along with the increase in population every year, it creates separate problems for village governments in running the government(Motors, Ral, \& Europe, 2016). Especially concerning public services for people living in the area. These services include population administration including the arrival of residents, transfer of souls, births, and deaths which are still carried out conventionally (Sujono, 2018) in the sense that they are recorded on a computer machine with standard office applications, while the current population is 8309 people who inhabit an area of $2460 \mathrm{~km}^{2}$ with a population density. 3378 people $/ \mathrm{km}^{2}$. This condition makes it difficult for the administrative staff of the Sukawening village government in terms of serving population administration so that services are not optimal among these services, namely managing resident documents, document damage, and file accumulation (Dedi, Iqbal, \& Fahroji, 2019), this condition becomes more severe when the Covid19 
pandemic is on. progress and reduced village operational hours.

This condition must be improved and reoptimized with breakthroughs so that public services for the community can be fulfilled again and even better, more efficient and effective, but still adhere to the Covid health protocol19. The breakthrough offered is to build a population administration service system in the village of Sukawening, Dramaga Bogor with the R\&D method, to build a web-based information system and population services so that it can be accessed from anywhere and mobile devices so that the difficulty of village staff in providing population documents services can be overcome and there are no crowds or queues of the community at the Sukawening village office, Bogor in meeting the needs of population documents, and services can still be carried out properly. So before people come to the village, residents have made transactions according to their needs and come to the village to validate and take documents. This is to avoid crowds of people.

This research has relevance to previous research, including in 2015 there was research on online-based village administration services with researchers including Yuliant Sibaroni, Erwin Budi Setiawan, Mahmud Imrona, Feby Ali Dzuhri entitled "Application of Web-Based Village Population Administration Services" with the problem of the manual correspondence process so that the format of the letter changes, data recording is inaccurate because it depends on the ability of the village apparatus so that a system application that can solve these problems is needed(Sibaroni, Imrona, Dzuhri, \& Setiawan, 2015).

The next research was conducted in Pelangwot village by Anton Firdaus, Nurudin Santoso, and Faizatul Amalia with the title "Development of a web-based village administration service application with SMS Gateway notification features" with a waterfall model for the development of a web-based system. This model was chosen because the design process was ordered and the steps were clear and structured so that it could solve the problems at hand(Firdaus, Santoso, \& Amalia, 2019). The main problem in this research is the lack of information dissemination of village information to the community and the distance to the village office is quite far with the road conditions which are rocky and not good. With the SMS Gateway feature, the community can order administrative needs to the village and get notifications when the order for documents for community needs has been completed.
The implementation of the web base as the basis for village administration services was also carried out by Tyas Rahmadani, Hanung Nindito Prasetyo, and Tedi Gunawan with the research object of the Wates Village Office of Tulung Agung Regency with the problem of lack of information dissemination about the requirements for making certificates to the village, storing letters with hard copies so that more pile up and easily lost, the process of making letters is still manual with the word processor not yet neatly recorded. Solving the problem by building a Tulung aging village administration management system(Rahmadani, Prasetyo, \& Gunawan, 2019).

\section{RESEARCH METHODS}

\section{Types of research}

The research method used in the development of this system is $R \& D$, with a descriptive method. Researchers conducted observations, interviews and saw the process of public services and data management of the population files of the Sukawening village office in Bogor.

From the results of these observations, it is suggested to be able to switch to a digital system. so that services can be implemented better, effectively and able to overcome the constraints of the high demand for document management of the population which continues to increase, in line with the increase in the population of the Sukawening village population. This makes the public service staff of the Sukawening village inconvenient in carrying out their functions.

\section{Time and Place of Research}

The research was conducted in July 2020 at the Sukawening village office, Bogor.

\section{Research Target / Subject}

Providing efficient and effective services and population data management can be done on a digital basis. During the Covid19 pandemic, by changing conventional services to digital-based with web technology to minimize the occurrence of mass crowds at the Sukawening village office, Bogor.

\section{Data, Instruments, and Data Collection Techniques}

Data collection was carried out in three ways, among others

a. Field studies and direct observations were carried out by visiting the government agency of the 
Sukawening Dramaga village, Bogor, which is located at Jl. Cimaburan No.3, Sukawening. b. Data collection by interviewing village staff who are directly related to day-to-day operations.

c. Study the literature by looking for reference sources from books and online journals

RAD is implemented in this study for several crucial reasons. This model was created to complement the shortcomings and weaknesses of previous system design models, including the waterfall model and its variants(Delima, Santosa, \& Purwadi, 2017).

The use of this model is intended to speed up the system being built to minimize costs and also shorter processing times, estimated to be more than fifty percent faster than other methods(Mishra \& Dubey, 2013).

The development of a web-based system in this study uses a code igniter framework as the main programming language, besides being supported by other tools that are no less important. These other tools play a role in fully supporting the performance of this framework so that the process is carried out better, in terms of time speed and compatibility with machines(Ellis, 2019). The tools used include javascript, ajax jquery, bootstrap, MySql, and sublime Text. Java script acts as the process behind the HTML that overwrites the view with the controller in the Codeigniter framework. This framework is based on OOP and uses MVC (modeling view control) technology. The position of javascript is in V (view). To bootstrap, it works with views as well as form modules that are ready to use and based on 00P.

Database management with MySQL and the Xampp engine is used. MySql was chosen in this study with the consideration that it is GPL (General Public License) and the ability to handle data is quite reliable(Sklar \& Trachtenberg, 2014) to be applied to data processing of Sukawening village population administration data, while ajax jquery is used as a bridge between the View and the Model that directly touches the database through the management controller (Cornelia, Gyorodi, Pecherle, Tamas, \& Roșu, 2009).

\section{Procedure}

The system development RAD model is the main solution to the discussion in this study, in addition to solving the main problem. Figure 1 below is a research framework that researchers are working on.

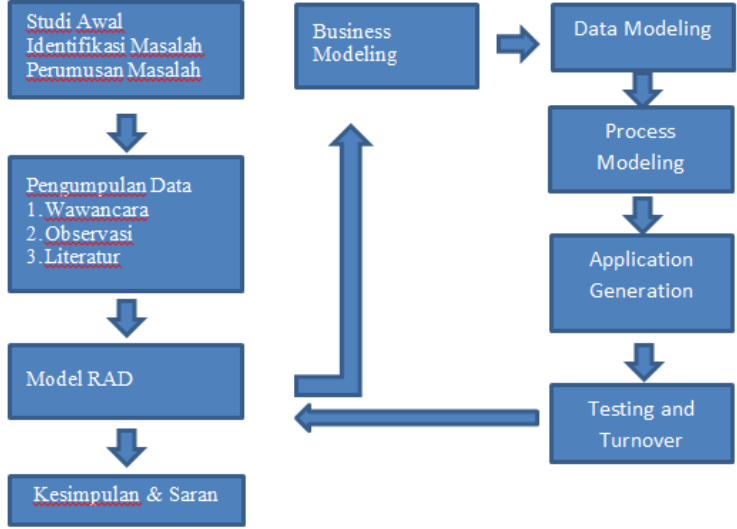

Figure 1. Research Framework

The research framework begins with problem identification and is then formulated to be raised as a writing topic. The next step is collecting data by conducting research or observation. In this observation stage, it was carried out by looking at the object directly to the village office of Sukawening and conducting interviews with several village staff, then the data and documents needed were sent via email and some through photos. For other supporting data needs, obtained through internet network data with the official website of the Bogor regency government.

The third stage of system development with the RAD model, where this model has five stages that must be carried out (Pressman, 2010). These stages include:

\section{Bussines Model}

Public services for the population documents of Sukawening village are carried out conventionally or manually so that the need for fast, precise, and efficient services is difficult to realize, in line with the conditions of the Covid-19 pandemic with a policy of avoiding crowds, it is also difficult to materialize so that it is urgent to migrate to the digital system. With the hope that these obstacles will be resolved.

The initial stage in the business model determines the system requirements plan, by holding discussions between analysts and users, especially the Sukawening village staff, to determine the scope of requirements of the system to be built. The data processing process begins with requests for resident documents including the creation of new documents, changes, and deletions such as death data. Data changes were carried out by village staff in the public service division based on previously owned data. The information generated by the system is in the form of a file 
format that is easily printed on hardcopy, for the needs of the population and village archives.

The following is a business activity model that is built, in this study the business model is described by the UML tool with a Use Case.

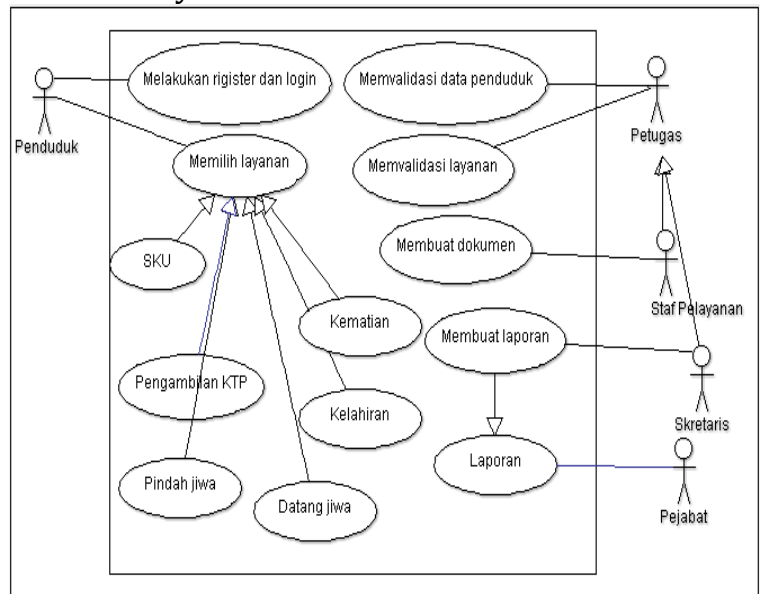

Figure 2. Use case diagram of Sukawening Village Population Administration

In Figure 2. the use case population registers based on KK and NIK data. Then the village officer verified the data. After the residents get a reply via notification, the resident can make documentmaking transactions as needed.

After the residents make transactions, the officers make documents according to the needs of the residents. For making SKUs (business certificates), validate the data with KK, KTP, and Domicile Information, then SKU in *.PDF format but without printing it first, printing is done when residents come to the village office. To make a birth certificate, validate the data from the KK, KTP, and marriage certificate provided that the resident's record is the original resident in the village of Sukawening.

\section{Data model}

Information obtained from the early stages of the business model is collected and defined into data entities. For this research, data entities were formed in the form of types of services, for example, services for documents of birth, death, soul transfer, and soul coming. These entities are translated back into the form of attributes, for example, a birth entity has an id, name, date of birth, and others, and the birth entity can be related to other entities according to the business model built.

Figure 3 below shows the relationship between entities, between residents who have document type services with officers who validate the prerequisite data and service staff who print documents, notifying the status of the letter to the resident concerned. The following is picture 9 .

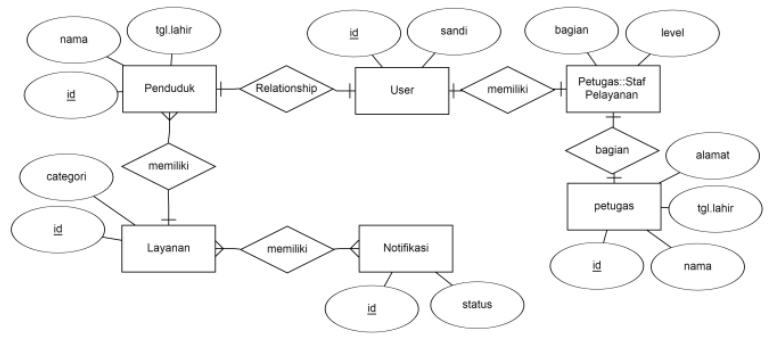

Figure 3. ERD diagram

\section{Process model}

In the process model phase, it is illustrated with an activity diagram that describes the activities of the user interacting with the system to create new data, modify data and delete data. The creation of new data is contained in the activity diagram of the birth of the population, namely by creating a new document (add data), which is shown in Figure 4.

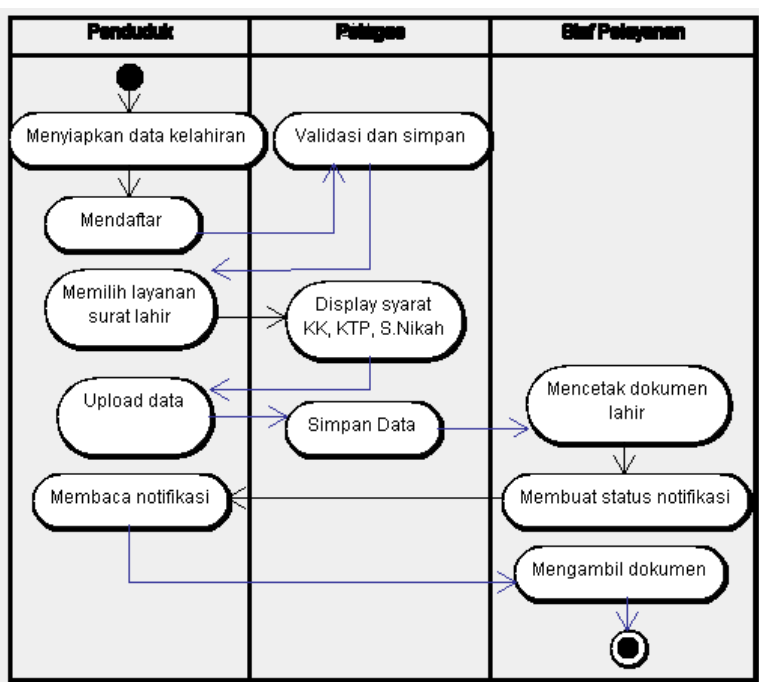

Figure 4. Activity diagram of birth certificate

The next process model is the arrival of the residents of the Sukawening village. The process of coming souls (add data) to check the first data validation is a domicile certificate, a certificate of moving from the old place, a copy of KK and KTP, if the requirements are complete, a digital cover letter is made and the service officer provides notification. Then the residents or residents take the cover letter to the village and take care of it at the local disdukcapil. Here's a picture 5. Activity diagram of a cover letter coming from the citizens. 


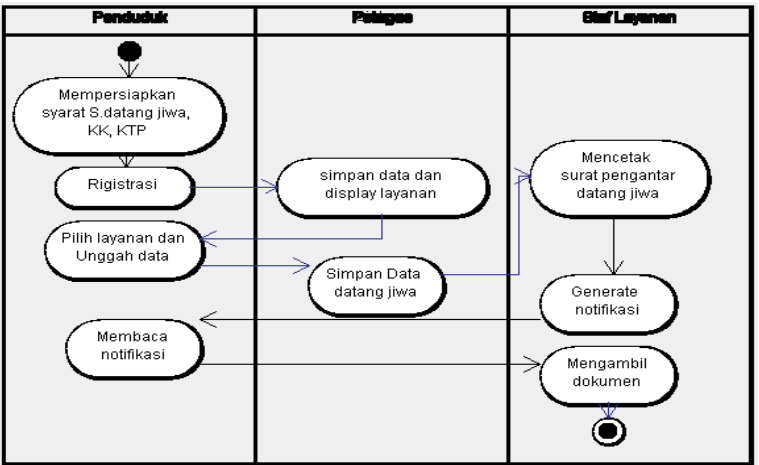

Figure 5. Activity diagram of a resident certificate of arrival

The next service process that reduces the population is a death cover letter. The two previous processes were to increase the population and death to reduce (delete data) the number of residents in the village of Sukawening, Bogor. Fewer requirements that must be fulfilled are a doctor's certificate, KTP, and KK. The process is the same as before, namely submitting online by selecting the destination service and uploading the documents according to the requirements then waiting for the notification to collect the required certificate. The process is more clearly illustrated in the activity diagram in Figure 6 as follows.



Figure 6. Activity diagram of the death certificate

\section{Application generation}

The fourth stage is generating code from the data model, into a prototype which is described in the form of a class diagram that can be directly generated into a program source code form.

Figure 7. The following is a class diagram from the description of the activity diagram in the process model. First, design the class diagram of the birth certificate. This process was triggered by residents who had previously registered themselves into the administrative system of the Sukawening village government and intended to make birth certificates for family members. The stipulated conditions must have a KK, KTP, and marriage certificate. Residents $\log$ in and choose the type of birth certificate service, then upload the required data and wait for data validation from village government staff until they get data submission information or notifications (can be in the form of SMS, WA, or email). After receiving the notification, the villagers came to the village government to collect a birth certificate. This is more clearly described in Figure 7.

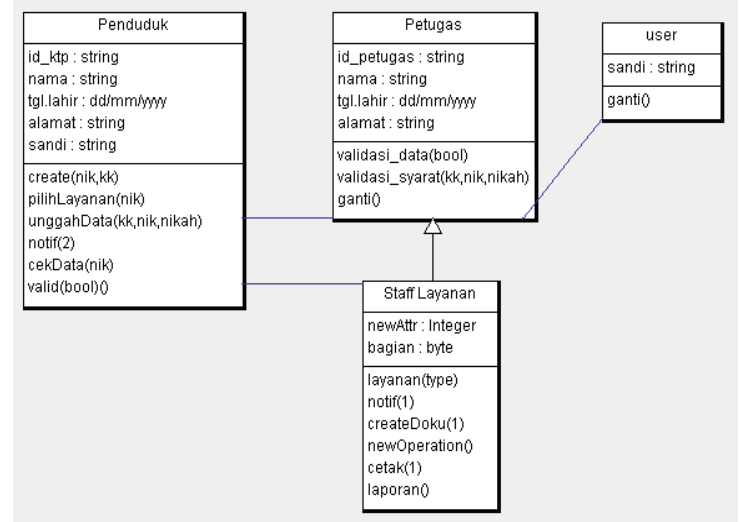

Figure 7. Class diagram of a birth certificate

The advanced design outlines the process of coming souls for migrant residents who intend to live permanently in the Sukawening village area. The business process flow starts with residents who apply for a certificate of moving from the village, but before that, they have to attach a certificate of moving from the old place, provide a domicile certificate in the new place and submit it to the village government via online. After selecting a service then uploading the required data and waiting for notification whether the requirements are complete or not. If complete, then the application for moving letter can be taken directly to the village office, but if not, it must be completed first. The following figure 8 explains the class diagram.

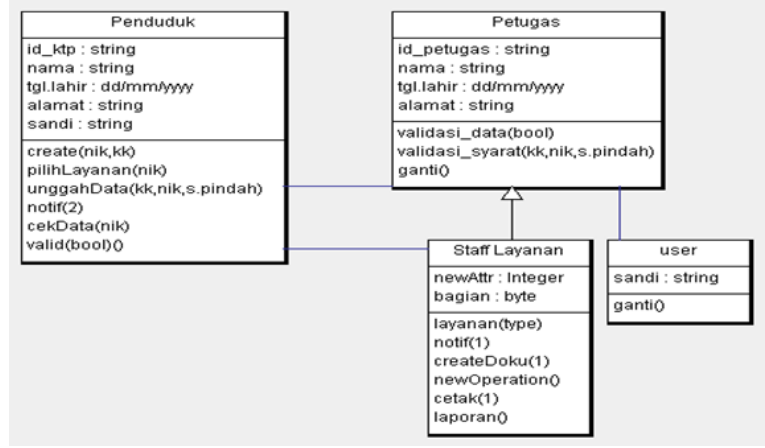

Figure 8. Class diagram of incoming letter residents 
The next stage is the elaboration of the death certificate process for residents which reduces the number of residents. The business process is not much different from the previous one, it's just that another requirement must be a doctor's or hospital's statement regarding the death of the resident. Trigger the process from residents who apply for online services by first logging in, then choosing a death notification service and uploading the predetermined requirements. Then the village officer checks the conditions according to the procedure and if it meets the requirements, the officer will be sent to the service to make a death certificate in digital form and provide notification to the population in question. The next process was that the villagers came to retrieve the printed death documents and the service staff reduced or deleted the resident id from the village database. For more details, see Figure 9.

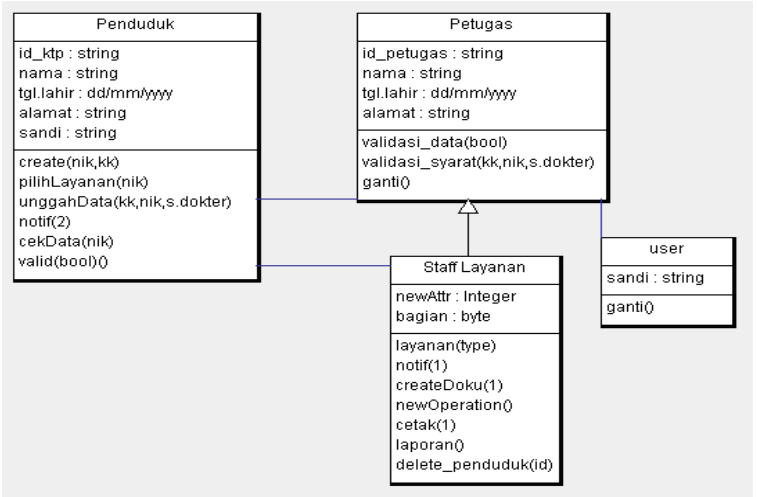

Figure 9. Class diagram of the death certificate

At this stage, generating a source code can be done with the help of a system design software tool, for example, Enterprise Architect (EA). In this study, the source code program was built using CodeIgniter tools with the OOP-based MVC platform so that the function or method formed is reusable.

\section{Testing and turnover}

The final stage of the RAD model involves the user in the program testing process, the user is likened to a consultant to see whether the coding results match the needs and convenience of the user or not. This process will take place until the user feels comfortable with the system being built. Users are involved intensively, while during the Covid pandemic like today, discussions can be done via video. For the testing process, it is carried out by the BlackBox method(Mohd. Ehmer \& Farmeena, 2012) in the sense that the data that is taken into account is the input data and the output results only, if the output is in accordance it is said the test is valid and if it is not suitable it is called invalid. The following is the BlackBox testing table.

Table 1. Population Registration

\begin{tabular}{|c|c|c|c|c|}
\hline \multirow[b]{2}{*}{ No } & \multirow[b]{2}{*}{ Scenario } & Result & Result & \multirow{2}{*}{$\begin{array}{l}\text { expecte } \\
\text { d } \\
\text { testing }\end{array}$} \\
\hline & & $\underset{n}{\text { Conclusio }}$ & $\begin{array}{l}\text { Conclusi } \\
\text { on }\end{array}$ & \\
\hline 1 & $\begin{array}{l}\text { part of the } \\
\text { fields are } \\
\text { empty }\end{array}$ & reject & $\begin{array}{l}\text { appropri } \\
\text { ate }\end{array}$ & valid \\
\hline 2 & $\begin{array}{l}\text { some of the } \\
\text { contents of the } \\
\text { data are } \\
\text { incorrectly }\end{array}$ & Received & $\begin{array}{l}\text { does not } \\
\text { match }\end{array}$ & invalid \\
\hline 3 & $\begin{array}{l}\text { fill in the data } \\
\text { completely } \\
\text { and incorrectly }\end{array}$ & reject & $\begin{array}{l}\text { appropri } \\
\text { ate }\end{array}$ & valid \\
\hline 4 & $\begin{array}{l}\text { fill in the data } \\
\text { completely } \\
\text { and correctly }\end{array}$ & Received & $\begin{array}{l}\text { appropri } \\
\text { ate }\end{array}$ & valid \\
\hline
\end{tabular}

In table 1, shows the test results in BlackBox and section no.2, there are errors in the coding with a lack of validation when the population registers. Meanwhile, other scenarios go according to expectations.

Table 2. Login Testing

\begin{tabular}{ccccc}
\hline No & Scenario & Result & Result & \\
\cline { 3 - 4 } & $\begin{array}{c}\text { Conclusio } \\
\text { n }\end{array}$ & $\begin{array}{c}\text { Conclus } \\
\text { ion }\end{array}$ & $\begin{array}{c}\text { expected } \\
\text { testing }\end{array}$ \\
\hline 1 & $\begin{array}{l}\text { one of the } \\
\text { empty fields }\end{array}$ & reject & $\begin{array}{c}\text { appropr } \\
\text { iate }\end{array}$ & Valid \\
\hline 2 & $\begin{array}{l}\text { both empty } \\
\text { fields }\end{array}$ & Reject & $\begin{array}{c}\text { appropr } \\
\text { iate }\end{array}$ & Valid \\
\hline 3 & $\begin{array}{l}\text { complete and } \\
\text { correct }\end{array}$ & Received & $\begin{array}{c}\text { appropr } \\
\text { iate }\end{array}$ & Valid \\
\hline
\end{tabular}

In table 2. The login test is as expected and is said to be valid because everything is by the system objectives.

Next is table 3. What is used to test upload the required files for each resident who manages the document The purpose of uploading files is for validation so that the residents who take care of the files are indeed original residents who live in the Sukawening village. Here's the table.

Table 3. Upload population files

\begin{tabular}{ccccc}
\hline & Scenario & Result & Result & \\
\cline { 3 - 4 } & $\begin{array}{c}\text { Conclusio } \\
\mathbf{n}\end{array}$ & $\begin{array}{c}\text { Conclusi } \\
\text { on }\end{array}$ & $\begin{array}{c}\text { expected } \\
\text { testing }\end{array}$ \\
\hline 1 & $\begin{array}{c}\text { Unformatted } \\
\text { file }\end{array}$ & Reject & $\begin{array}{c}\text { appropri } \\
\text { ate }\end{array}$ & valid \\
\hline 2 & $\begin{array}{c}\text { Incorrect file } \\
\text { size }\end{array}$ & Reject & $\begin{array}{c}\text { appropri } \\
\text { ate }\end{array}$ & valid \\
\hline 3 & $\begin{array}{c}\text { files } \\
\text { according to } \\
\text { the rules }\end{array}$ & Received & $\begin{array}{c}\text { appropri } \\
\text { ate }\end{array}$ & valid \\
\hline
\end{tabular}


The last table in this black box test is a form of transaction in the form of determining the services needed by the population. There are five choices provided, namely SKU, coming souls, transferring citizens, death, birth, and making ID cards. Currently, the policy of the government is that the village government provides more cover letters for higher-level document processing. For example, in making e-KTP, the task of the village is to provide an introduction and at the same time validate that the people who administer the letter are indeed residents. So the village government acts as a facilitator.

The following is table 4 . Which shows the transactions of the interests of the residents in processing letters as needed.

Table 4. Transactions of resident document requirements

\begin{tabular}{ccccc}
\hline No & Scenario & Result & Result & \\
\cline { 3 - 4 } & $\begin{array}{c}\text { Conclusio } \\
\mathbf{n}\end{array}$ & $\begin{array}{c}\text { Conclus } \\
\text { ion }\end{array}$ & $\begin{array}{c}\text { expected } \\
\text { testing }\end{array}$ \\
\hline 1 & $\begin{array}{c}\text { not choose a } \\
\text { service }\end{array}$ & Reject & $\begin{array}{c}\text { appropr } \\
\text { iate }\end{array}$ & valid \\
\hline 2 & choose a service & Received & $\begin{array}{c}\text { appropr } \\
\text { iate }\end{array}$ & valid \\
\hline
\end{tabular}

\section{RESULTS AND DISCUSSION}

This research produces a population data management information system in Sukawening village which is located in Bogor district, the resulting system is the implementation of the RAD model. The stage consists of 5 major steps, and the results of this implementation are in the 5th stage in the form of a view of the design results. The following is the admin login view to maintain data security.

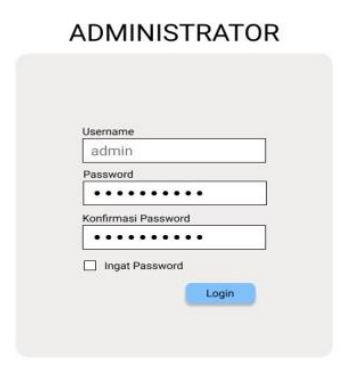

Figure 10. Login manager

In Figure 10. Blackbox testing has been carried out as shown in table 1. The login form acts as a system safeguard so that people who do not have rights cannot enter.



Figure 11. View index page

The index page is an initial view of the administrative management system for the Sukawening villagers.

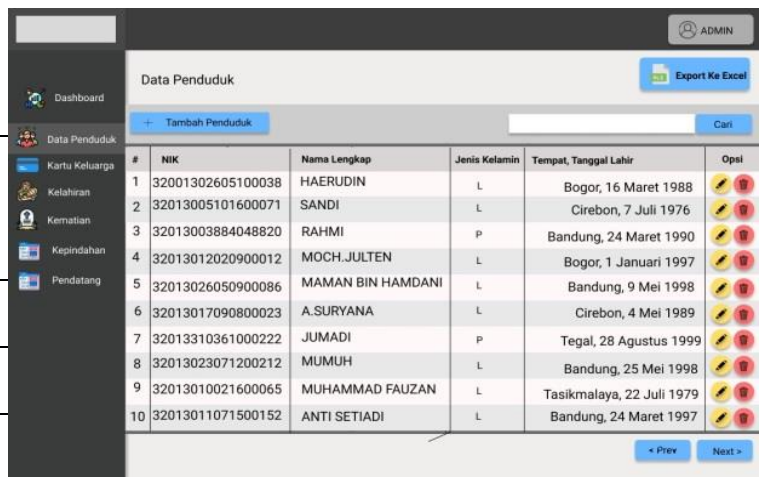

Figure 12. View population data

In Figure 12. Shows the data of the Sukawening villagers who have been registered in the village administration management system. For residents who have not been registered, when they process the population documents, they are obliged to register. This is very important because it will be easy to obtain information on the number of real residents who live in the area as a first step in submitting a budget for village development.

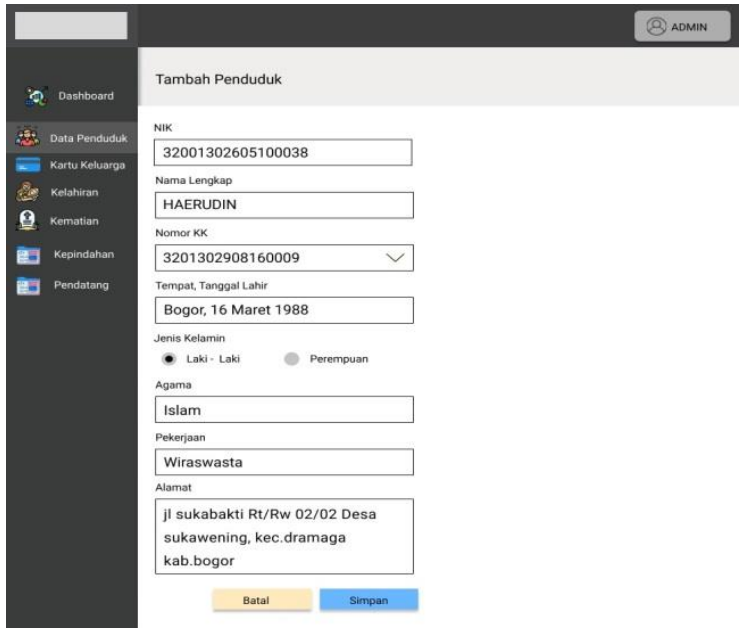

Figure 13. View added population data 
Figure 13. Is added population data resulting from citizen submissions for administrative purposes, this view is based on data uploaded by residents in the form of documents including $\mathrm{KK}$, KTP, and others according to the needs of residents and the conditions that have been determined by the village SOP.

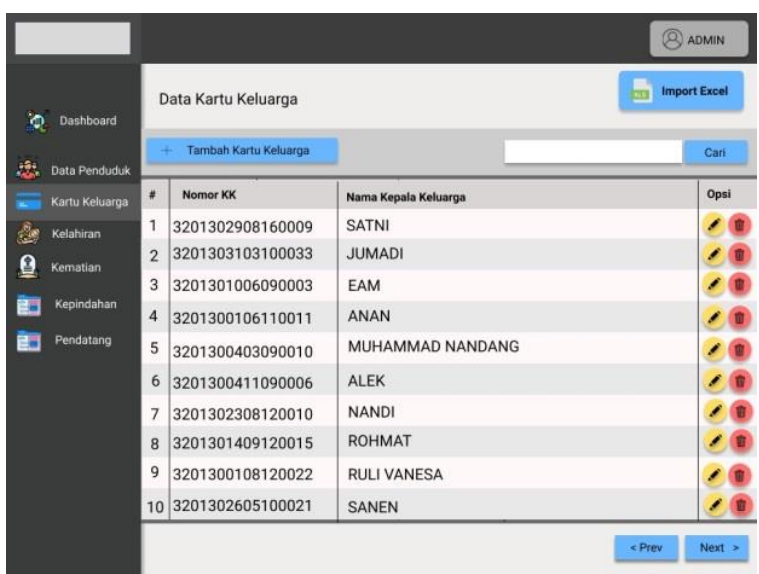

Figure 14. View Family Card data

Family card data (KK) was previously stored in paper files and digital form with the ${ }^{*}$.exl format. In Figure 14. Family card data can also be imported from * .exl files so that the data storage of the resident's $\mathrm{KK}$ is better than before because the data storage in the form of a database is easier to manage with the system being built.



Figure 15. View details of Family Card data members increase and deaths that make family members' data decrease, as well as moving souls with a change of address.

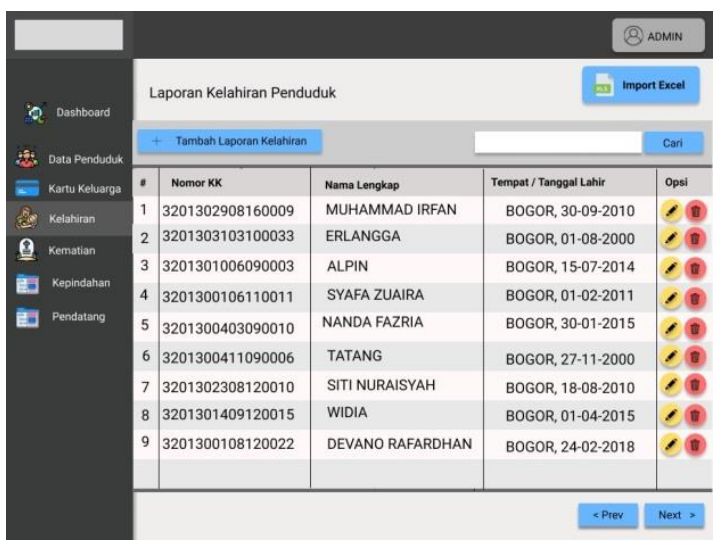

Figure 16. View of birth data

Birth data will be updated if some residents or residents report the birth of their family. The village government provides a certificate based on the request of the community through a system that is submitted first and the officer or manager validates the data based on the existing prerequisites. The officer provides notification to the applicant via SMS, WA, and others. This is done so that in the village office there is no accumulation of people/communities managing documents.

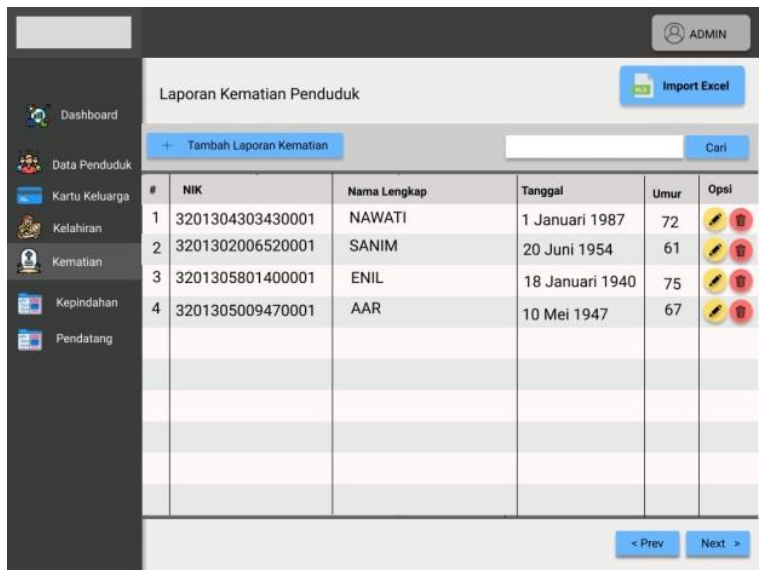

Figure 17. View of mortality data

View death data, mortality data reduces the population, as well as reduces data on the KK of the population concerned so that data updates must be made to the district government and village government. In Figure 18. There is a detailed update of the mortality data contained in the system being built.

Family card data can be changed if needed, changes that occur are usually births so that family 


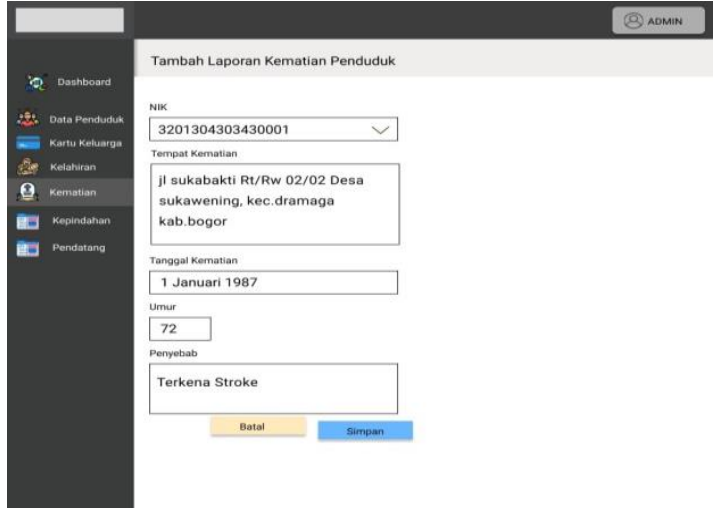

Figure 18. View detailed mortality data

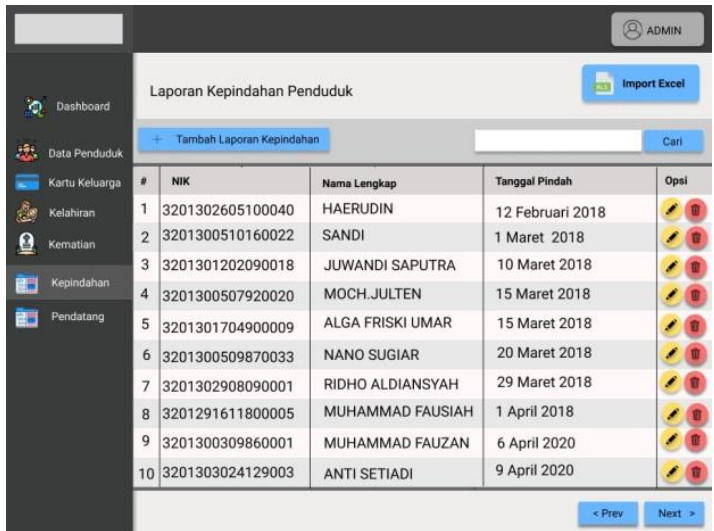

Figure 19. View details of moving data

Residents have moved souls, so the person concerned is required to submit a cover letter to move from the village by showing a domicile certificate from the new place.

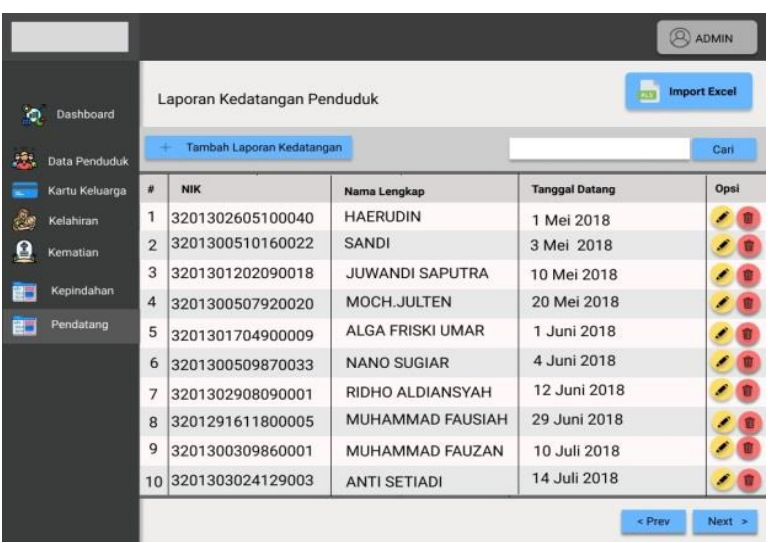

Figure 20. View detailed arrival data

The arrival of residents has a good impact on the Sukawening village government because the increasing number of residents living in the area will increase the budget and income for the village. In addition, residents who come are required to report themselves by submitting online and uploading documents, including a letter of moving from their old residence, KK, KTP. The village government makes an introduction through the system with an officer who carries out verification, and when the letter is finished, the service staff will notify the residents or residents concerned.

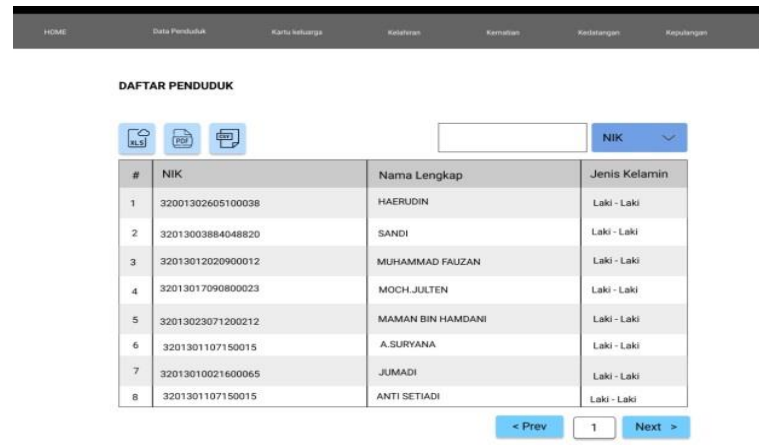

Figure 21. View population report data

Population data reports, both general and specific, are made by the service staff or the village secretary. The report in Figure 21. can be generated once a month and annually which will be useful as future village policy steps.

Reports can be classified based on data on births, deaths, arrivals, and transmissions. So that with this system, the management of population data as well as administration related to community members can reduce the incidence of physical contact, but the needs of residents can still be served properly.

\section{CONCLUSIONS AND SUGGESTIONS}

\section{Conclusion}

The creation and development of population data management applications related to public services continue to be improved and breakthroughs are sought during the Covid19 pandemic, one of which is services through online applications. With this application, there are many advantages, including, the population administration needs of the Sukawening village community can still be served properly without violating the Covid19 protocol because the number of arrivals of community members to take care of documents is less and it is scheduled with the application of this system. The majority of residents who come take the finished documents and it doesn't take long so that the accumulation of community members at the Sukawening village office does not occur. Reports for a certain period can be generated easily. The drawback of this research is that the notification feature is still done manually via SMS, WA so that residents who do not have telephone contact do not receive notifications. 


\section{Suggestion}

For further development, a notification feature can be added via SMS but made in the form of an SMS gateway that is connected to the system, an SMS gateway can be made with GPL (general public license) Gammu or with other facilities.

\section{REFERENCES}

BPS, B. P. S. (2019). Kecamatan dramaga dalam angka 2019. BPS Kabupaten Bogor. Retrieved from

https://bogorkab.bps.go.id/publication/201 9/09/26/ea6b7816ceccd3caab9844bc/keca matan-dramaga-dalam-angka-2019.html

Cornelia, G., Gyorodi, R., Pecherle, G., Tamas, L., \& Roșu, A. (2009). Web 2.0 Technologies with jQuery and Ajax. Journal of Computer Science and Control Systems, 2. https://doi.org/10.1201/b13124-7

Dedi, Iqbal, M., \& Fahroji, W. (2019). Sistem Informasi Administrasi Kependudukan Berbasis Web di Kelurahan Sangiang Jaya. Seminar Nasional APTIKOM (SEMNASTIK) 2019, 306-313. Retrieved from https://publikasi.dinus.ac.id/index.php/sem nastik/article/download/2806/1754

Delima, R., Santosa, H. B., \& Purwadi, J. (2017). Development of Dutatani Website Using Rapid Application Development. IJITEE (International Journal of Information Technology and Electrical Engineering), 1(2), 36-44.

https://doi.org/10.22146/ijitee.28362

Ellis, R. (2019). Framework CodeIgniter. Retrieved May 26, 2021, from British Columbia Institute of Technology. website: https://www.codeigniter.com/userguide3/o verview/at_a_glance.html

Firdaus, A., Santoso, N., \& Amalia, F. (2019). Pembangunan Sistem Aplikasi Pelayanan Administrasi Desa Berbasis Web dengan Fitur Notifikasi Sms Gateway ( Studi Kasus Desa Pelangwot ). Jurnal Pengembangan Teknologi Informasi Dan Ilmu Komputer (JPTIIK) Universitas Brawijaya, 3(2), 8986-8991.

Mishra, A., \& Dubey, D. (2013). A Comparative Study of Different Software Development Life Cycle Models in Different Scenarios. International Journal of Advanced Research in Computer Science and Management Studies, 1(5), 23217782. $\quad$ Retrieved from http://www.ijarcsms.com/docs/paper/volu me1/issue5/V1I5-0008.pdf

Mohd. Ehmer, K., \& Farmeena, K. (2012). A Comparative Study of White Box, Black Box, and Grey Box Testing Techniques. International Journal of Advanced Computer Science and Applications, 3(6), 12-15. https://doi.org/10.1017/CB0978110741532 4.004

Motors, G., Ral, \& Europe, W. (2016). Permendagri 47 Tahun 2016 Tentang Administrasi Pemerintahan Desa. 2016(June), 4-13.

Pressman, R. S. (2010). Software Quality Engineering: A Practitioner's Approach. In Software Engineering: A Practitioner's Approach. Retrieved from http://gen.lib.rus.ec/book/index.php?md5=E 1368B6CA046D3F456124359804C640F

Rahmadani, T., Prasetyo, H. N., \& Gunawan, T. (2019). Aplikasi Pelayanan Administrasi Desa Berbasis Web Studi Kasus : Kantor Desa Wates Kabupaten Tulungagung Application of Village Administration Services Web Based Case Study: Wates Village Office Tulungagung District. 5(2), 1021-1032. Retrieved from https://openlibrary.telkomuniversity.ac.id/p ustaka/files/152539/jurnal_eproc/aplikasipelayanan-administrasi-desa-berbasis-webstudi-kasus-kantor-desa-wates-kabupatentulungagung.pdf

Sibaroni, Y., Imrona, M., Dzuhri, F. A., \& Setiawan, E. B. (2015). Aplikasi Pelayanan Administrasi Penduduk Desa Berbasis Web Programing. Seminar Nasional Aplikasi Teknologi (SNATi), 6(1), 1-6. Retrieved from http://download.portalgaruda.org/article.ph p?article $=356496 \&$ val=576\&title=Aplikasi Pelayanan Administrasi Penduduk Desa Berbasis Web Programing

Sklar, D., \& Trachtenberg, A. (2014). MySQL Cookbook, 3rd Edition. In R. Roumeliotis \& A. MacDonald (Eds.), Angewandte Chemie International Edition, 6(11), 951-952. (3rd ed.). United States of America: O’Reilly Media, Inc. Retrieved from https://www.oreilly.com/catalog/errata.csp? isbn=9781449363758

Sujono, S. (2018). Penerapan Aplikasi Sistem Informasi Kependudukan Berbasis Web Pada Kantor Kepala Desa Puput Kec. Simpangkatis. Simetris: Jurnal Teknik Mesin, Elektro Dan Ilmu Komputer, 9(1), 707-716. https://doi.org/10.24176/simet.v9i1.2078 